\title{
Arnold Geulincx: Scepticism and Mental Holism
}

\section{Introduction}

The Flemish thinker Arnold Geulincx (1624-69) is known among historians of philosophy as one of the founders of modern occasionalism, the view that God alone, not creatures, exerts causal efficacy. ${ }^{1}$ Being counted among the modern occasionalists, Geulincx has also been associated with a wide variety of philosophical tendencies. Whereas for some, he is merely a minor disciple of Descartes, for others, he is the missing link between Descartes and Spinoza. ${ }^{2}$ A certain line of interpretation (notably represented by Cassirer) sees Geulincx as a precursor of Kant. ${ }^{3}$ According to de Vleeschauwer, Geulincx is the first thinker who explicitly equated knowing and doing, thus paving the way for the constructivism of Giambattista Vico and Benedet-

1 Compare this brief characterisation of occasionalism with that of Clatterbaugh in his The Causation Debate in Modern Philosophy 1637-1739 (New York: Routledge, 1999), 97. The other founders of modern occasionalism were Louis de La Forge (1632-66) and Géraud de Cordemoy (1626-84), although Geulincx developed his own occasionalistic conception independently of them. See Jean-Christophe Bardout, "Occasionalism: La Forge, Cordemoy, Geulincx," in A Companion to Early Modern Philosophy, ed. Steven Nadler (Boston: Blackwell Publishers, 2002), 140-51. Modern occasionalism would reach its apex with Nicolas Malebranche (1638-1715); regarding the affinities and divergences between Geulincx's and Malebranche's occasionalism, see Steven Nadler, "Knowledge, Volitional Agency and Causation in Malebranche and Geulincx," British Journal for the History of Philosophy 7, no. 2 (1999): 263-74. I have explicitly said "modern" occasionalism, for a variation of this view (or group of related views, as occasionalism is not a homogeneous trend or school) already existed in medieval Muslim philosophy. See Ludwig Stein, "Antike und mittelalterliche Vorläufer des Occasionalismus," Archiv für Geschichte der Philosophie 2, no. 2 (1888): 193-245; also Dominik Perler and Ulrich Rudolph, Occasionalismus: Theorien der Kausalität im arabisch-islamischen und im europäischen Denken (Göttingen: Vandenhoeck \& Ruprecht, 2000). For a thorough reconstruction of the emergence of occasionalism after Descartes, see Rainer Specht, Commercium mentis et corporis. Über Kausalvorstellungen im Cartesianismus (Stuttgart-Bad Canstatt: Friedrich Frommann Verlag [Günther Holzboog], 1966).

2 This is Bernard Rousset's main thesis in his posthumous work Geulincx entre Descartes et Spinoza (Paris: Vrin, 1999). In the early eighteenth century, Geulincx was accused of Spinozism by Christian Thomasius and Ruarda Andala. His philosophy has been suspected of Spinozism ever since. See H. J. de Vleeschauwer, "Three Centuries of Geulincx Research: A Bibliographical Survey,” Mededelings van die Universiteit van Suid-Afrika 1 (1957): 1-72, and especially Han van Ruler, "Geulincx and Spinoza: Books, Backgrounds and Biographies,” Studia Spinozana 15 (2006): 89-106.

3 However, Cassirer also stresses the large gap between Kant and Geulincx. See Ernst Cassirer, Das Erkenntnisproblem in der Philosophie und Wissenschaft der neueren Zeit, 3rd ed. (Berlin: Verlag Bruno Cassirer, 1922), 1:552. 
to Croce. ${ }^{4}$ Despite these multiple affiliations and fatherhoods-or perhaps because of them-Geulincx's philosophy has rarely been studied for its own sake and remains widely unknown. ${ }^{5}$ With the exception of de Lattre's seminal work, ${ }^{6}$ we are still awaiting a thorough study of Geulincx's multifaceted thought.

Without pretending to fill this lacuna, the present study will focus on Geulincx's remarkable approach to human cognition and its extent, which constitutes the basis of his entire philosophy, including the occasionalism for which he is known. Geulincx's position in this regard is at first glance extremely ambivalent, if not incoherent. On the one hand, he seems to deny the possibility that the human mind may attain genuine knowledge and to embrace a hopeless scepticism. On the other, he presents his own philosophy as a true metaphysics, which he defines as knowledge of things as they are in themselves, independent of our consideration. Moreover, in his metaphysics, he endorses a quasi-pantheistic conception-quite reminiscent of Spinoza's-that prima facie is the antipode to scepticism. I will try to make sense of these disparate claims and argue that they actually form a coherent whole. In particular, I will show how Geulincx's sceptical distrust of our cognitive powers leads him to embrace a form of mental holism, according to which the human mind is just a parcel or sub-region within an infinite intellect. Furthermore, I will examine how our containment within God's mind enables us to grasp necessary truths but prevents us from understanding the created world, whose existence is a contingent fact that is unaccountable by reason. The example of Geulincx will thus reveal that a fecund scepticism can, by discarding certain objects as unknowable, open up areas of exploration that were hitherto considered impenetrable. I will structure my exposition as follows. In the next section, I will examine Geulincx's general position on human cognition and its apparent inconsistencies. In the third section, I will reconstruct Geulincx's reasoning process in the first part of his True Metaphysics (Metaphysica vera), which seamlessly moves from an initial scepticism to ascer-

4 See H.J de Vleeschauwer, "Les antécédants du transcendentalisme. Guelincx et Kant," Kant-Studien, 45, 1-4 (1953): 246-47.

5 Geulincx's only significant follower was Richard Burthogge (1637/38-1705), who studied at the University of Leiden in 1661 and almost certainly attended Geulincx's lectures. Geulincx's influence is clearly recognisable in his Essay upon Reason and the Nature of Spirits (London: Dunton, 1694), which he dedicated to John Locke. Regarding Burthogge's thought in connection with Geulincx's, see Cassirer, Erkenntnisproblem, 1:543-53; Michael R. Ayers, "Richard Burthogge and the Origins of Modern Conceptualism," in Analytic Philosophy and History of Philosophy, ed. Tom Sorell and G.A.J. Roger (Oxford: Clarendon, 2005), 179-200. Furthermore, scholars have unsuccessfully attempted to establish a link between Geulincx and Leibniz, mainly due to Leibniz's simile of the two clocks, which also appears in Geulincx, despite the fact that Eduard Zeller conclusively demonstrated in 1884 that there is no such influence. See Eduard Zeller, "Über die erste Ausgabe von Geulincx' Ethik und Leibniz’ Verhältnis zu Geulincx’ Occasionalismus,” Sitzungsberichte der Königlich Preußischen Akademie der Wissenschaften zu Berlin 29, no. 2 (1884): 673-95.

6 Alain de Lattre, L'occasionalisme d'Arnold Geulincx (Paris: Éditions de Minuit, 1967). 
taining our containment in God's mind. ${ }^{7}$ In the fourth section, I will examine Geulincx's demonstration of the existence of a corporeal world by means of the notion of time. In the fifth and final section, I will focus on some aspects of Geulincx's critique of Scholastic philosophy which indirectly illuminate his own philosophical approach.

\section{Scepticism and the Priority of the Knower over the Known}

Geulincx's epistemological position is summarised in an explanatory note from his short treatise Metaphysics according to the Peripatetic Mind (Metaphysica ad mentem peripateticam). ${ }^{8}$ Neither the nature of this treatise (which I will briefly discuss in the last section) nor the context in which Geulincx inserts this explanatory note is important for us now. The text in question reads as follows:

We should not consider things insofar as they are sensible (i.e., insofar as they enter into the senses under a certain aspect), nor insofar as they are intelligible (i.e., insofar as we think of them in a certain way). Yet we cannot consider them as they are in themselves [ut sunt in se], from which we see our great imperfection. Therefore, it only remains for us to do (which we can and must do) that in the judgment of the mind, whenever we apprehend something under a certain mode of our thought (which we always do, and we cannot do otherwise while we are human beings), we always keep in mind that the thing is not in itself as it is apprehended by us. Even if we always attribute the appearances of the senses and the intellect to the things themselves, there is nevertheless something divine in us that always tells us that it is not thus, and only in it does our wisdom [sapientia] consist, insofar as we are human beings. ${ }^{9}$

This passage distinguishes three ways of considering things: as sensible, as intelligible, and as they are in themselves. The first two ways show how things are in relation to us, both to our senses and to our intellect. Due to their relative character, these two ways of considering things do not count as real knowledge. Only the third way can

7 All references to Geulincx's works are from the standard edition: Arnoldi Geulincx Antverpiensis Opera Philosophica, ed. Jan Pieter Nicolaas Land, 3 vols (Den Haag: M. Nijhoff, 1891-93); henceforth OP. The English translations of Geulincx in this paper are mine.

8 OP 2:300-301; ad pag. 200.

9 OP 2:300-301; ad pag. 200: "Nos non debemus res considerare prout sunt sensibiles (id est, sub certa specie incurrunt in sensum); neque ut sunt intelligibiles (id est, sub certo modo a nobis cogitantur). Sed ut sunt in se, non possumus eas considerare; unde videmus magnam nostram imperfectionem. Hoc unum igitur restat nobis faciendum (quod et possumus et debemus facere), ut judicio mentis, quotiescunque rem aliquot sub modo aliquot cogitationis nostrae apprehendimus (quod equidem semper facimus, nec possumus aliter dum homines sumus), semper hoc teneamus, rem non esse ita in se, ut apprehenditur a nobis. Etiamsi nos semper phasmata sensus et intellectus ipsis rebus tribuamus; tamen est aliquid divinum in nobis, quod semper dicit nobis, non esse sic; et in hoc unico consistit nostra, quatenus homines sumus, sapientia.” 
rank as knowledge proper, insofar as it apprehends things as they are in themselves; i. e., independent of our consideration. Yet this description already shows that knowledge is out of our reach, for we cannot, as it were, go beyond ourselves and consider things from a standpoint that differs from ours. We seem, therefore, to be trapped in a deadlock and to be unable to overcome our distorted view of things. In view of this predicament, Geulincx argues, there is only one thing that we can (and must) do; namely, to always bear in mind that things are not the way that we perceive and conceptualise them. This awareness (or scruple) is the only knowledge available to us and is something divine in us (aliquid divinum in nobis), for in a way, it raises us above our cognitive imperfection, yet without thereby remedying our condition.

Judging by this passage, Geulincx's position can be described as a resigned scepticism. Yet his statements in other passages, as well as his attempt to develop a metaphysical system, seem to contradict the epistemological stance described above. In another explanatory note, he affirms that a true metaphysics considers things as they are in themselves, independent of us. ${ }^{10}$ Moreover, he titles the exposition of his own philosophy True Metaphysics, thus suggesting that he is in possession of the knowledge that-according to the passage quoted above-human beings are constitutively unable to attain. Does this mean that Geulincx's views concerning human knowledge are simply inconsistent? In what follows, I will show that this is not the case and that Geulincx's metaphysical endeavour is actually a sagacious solution to the predicament described above. Between the mere consideration of things as they appear to us and the (unattainable) apprehension of things as they are in themselves, there is, for Geulincx, a third possibility. This third way refrains from considering things and focuses on the consideration of ourselves, i.e., of our minds regardless of their particular contents. Given the general uncertainty of our knowledge, our only certainty is the mere fact that we think and perceive, irrespective of the objects that are thought and perceived. Geulincx calls this fact the "prerogative of the knower over the known."11 Certainly, knowledge requires both a knower and a known thing. Yet whereas the latter can somehow be absent-for instance, when we errthe former must necessarily exist. Therefore, the only possible way of expanding our knowledge, once we realise that things are not the way we apprehend them, is by taking our own thought as the point of departure for our philosophical inquiry. For Geulincx, sceptical doubt is thus the negative flipside of the knower's priority over the known things. Knowledge does not have its source in the known objects, but in the knower's self-certainty. Thus, our entire knowledge of the world must exclusively derive from a careful inspection of ourselves, without (unjustifiably) assign- 
ing any reality to our perceptions beyond our consciousness. ${ }^{12}$ This will be Geulincx's strategy in his True Metaphysics, as I will show in the next section.

Before examining Geulincx's self-explorative approach more closely, we must clear up a possible misunderstanding. By proposing an exploration of our own thought, Geulincx might seem to be engaging in the second kind of consideration of the three listed above; i.e., the consideration of intelligible things. Yet Geulincx does not simply dismiss sensible knowledge in favour of intellectual knowledge, understanding the latter as a knowledge by means of concepts. For him, both of them are equally unreliable, insofar as they are concerned with particular contents-be they sensible or intellectual-thus giving precedence to the known over the knower. Therefore, the self-inspection that Geulincx proposes does not have the meaning of an inquiry into our basic set of categories or our conceptual apparatus. For the same reason, for him, the phrase "self-inspection" does not designate an investigation of the human soul as a specific object among others or as a specific realm of reality differentiated from others, for such an investigation would presuppose a prior classification of beings, a preexistent map of reality, as it were, which we uncritically take for granted before exploring our own thought. This kind of implicit assumption is precisely what Geulincx's "prerogative of the knower over the known" calls into question. ${ }^{13}$ Hence, the only valid starting point of knowledge is the consideration of our thought simpliciter, without further qualifications. One might rightly observe that if we put aside our entire set of basic concepts, the philosophical investigation is left with nothing. If our only certainty is the mere fact that we think, regardless of what we think and how we think, we can justifiably claim that our initial certainty is almost nil. Yet this objection, far from undermining Geulincx's endeavour, actually strengthens it. At the beginning of the philosophical inquiry, Geulincx demands: "Before entering metaphysics, you must consider yourself empty of all knowledge." ${ }^{14}$ The knowledge that Geulincx is seeking cannot depend on a prior knowledge, for that would contradict the prerogative of the knower over the known. Therefore, and in

\footnotetext{
12 In Geulincx's Ethics, self-inspection is-together with self-contempt-one of the constituents of humility, which he views as the most important of the four cardinal virtues (that is: diligence, obedience, justice, and humility). Self-inspection thus constitutes the foundation of both true cognition and ethics. See OP 3:30-37. Regarding the ethical significance of self-inspection in Geulincx, see Andrea Sangiacomo, "Defect of Knowledge and Practice of Virtue in Geulincx's Occasionalism," Studia Leibnitiana 46, no. 1 (2014): 46-63.

13 One might wonder to which extent Geulincx can actually carry out this questioning of given categories, for he presupposes the real distinction between the corporeal and the mental, in which respect he still moves within a Cartesian framework. See the conclusion to this paper. For a thorough comparison between Descartes and Geulincx regarding their criticism of received categories and notions, see Mark Aalderink's Philosophy, Scientific Knowledge, and Concept Formation in Geulincx and Descartes (Utrecht: Zeno, 2010).
}

14 OP 2:140: "[...] necessum est, ut ante ingressum in Metaphysicam consideres the ipsum ut vacuum ab omni scientia [...]" 
order to attain indisputable certainty, the philosophical inquiry must start from a zero-point of knowledge.

\section{Geulincx's Autology: Self-Inspection and Mental Holism}

Geulincx's main philosophical work, the treatise True Metaphysics, ${ }^{15}$ begins with an Autology (or self-knowledge), continues with a Somatology (or knowledge of the corporeal world), and concludes with a Theology (or knowledge of God). ${ }^{16}$ In this chapter, I want to focus on the first sections of his Autology and show how Geulincx's initial scepticism seamlessly expands into the affirmation of an all-encompassing mind, of which the human mind is a limited parcel or sub-region. As already noted, the priority of the knower over the known dictates that a true metaphysics cannot be derived from a previous knowledge. Thus, in a similar way to Descartes in his Meditations (and obviously following his example), Geulincx establishes that we must doubt everything before entering the path of true knowledge. Yet he insists that this procedure has nothing to do with the usual attitude of the sceptics, who do not aspire to knowledge and are content with remaining in permanent doubt. In contrast to the sceptics, Geulincx intends to attain genuine knowledge while at the same time remaining within the limits of the sceptical scruple described above. Therefore, the general doubt that he proposes at the beginning of his True Metaphysics is only the threshold to a fundamental, radical knowledge. ${ }^{17}$

Geulincx loosely adopts Descartes's meditative approach in the first reflections of his Autology, only to derive quite different conclusions from Descartes, as we will soon see. Thus, he starts by observing that even if I consider myself empty of knowledge and uncertain of everything, it is indubitable that I exist as a thinking being. Therefore, cogito, ergo sum. Even the stubbornest sceptic would have nothing to counter this certainty, which Geulincx calls the "prima scientia" (i.e., first discernment or first knowledge) of his Autology. ${ }^{18}$ All further knowledge that we might attain must entirely derive from this first certainty, without surreptitiously introducing foreign elements. It is noteworthy that Geulincx avoids-as much as he can-using the word "res" with respect to the ego, for the fact that I think does not entail that I am a self-sufficient thing or a substance. To draw such a hasty conclusion would be a relapse into the "reifying" thinking that Geulincx is trying to overcome and to privilege known things over the knower. As we will see, it is precisely this strict adherence to

15 OP 2:139-98; annotations in the same volume, 266-310.

16 The treatise also contains an introduction in which Geulincx elucidates, among other things, the relationship between metaphysics and the rest of the sciences.

17 See Rousset, Geulincx entre Descartes et Spinoza, 50.

18 OP 2:147. 
his method of self-inspection and the refusal to reify thoughts that will enable Geulincx to overcome the limited scope of the ego. In any case, having ascertained that I exist as a thinking being, I observe an infinite variety of thoughts or modi cogitandi in myself. I am aware that I see, touch, hear, etc. Besides these kinds of sensations, I also observe feelings in myself such as love, fear, and hatred, as well as mental operations such as affirming, associating, denying, inferring, and the like. All these things are modes of my thought of which I am aware and certain. We can thus establish a second discernment, immediately derived from the first, to wit: I have an infinite variety of modes of thought. ${ }^{19}$ Geulincx observes that the ascertainment of this truth does not commit us to affirming the existence of things corresponding to these diverse modi cogitandi. If I perceive a light, for instance, that does not mean that there is indeed a light beyond my perception, or, in the event that there is, that the thing in question is the way I perceive it. The same applies to all the things I hear, smell, touch, etc. Nonetheless, it is undeniable that I have such perceptions, which are nothing but modes of my thought.

Having established that I think and that I contain an infinite variety of modi cogitandi, Geulincx goes a step further by observing that despite the plurality of thoughts I find in myself, I am something (quaedam) that is simple, undivided, and devoid of parts. ${ }^{20}$ I may have a body that is divisible into parts-which is still uncertain-but as a thinking being, I have no parts. Certainly, I think and perceive a multitude of diverse things, yet the one that thinks and perceives this diversity is one and the same, and hence simple. When I see, touch, and even when I philosophise, I am, in all these different actions, the same "I." I will return to the simplicity of the ego in the next section, when I examine Geulincx's demonstration of the existence of a corporeal world. The ascertainment of my simplicity leads to the next, decisive discernment; namely, that there are many thoughts in me that do not depend on me (multae sunt in me, quae a me non dependent cogitationes). ${ }^{21}$ I observe a plurality of thoughts and sensations in myself that do not arise whenever I want. The simple act of observing the world around me fills me with impressions that take place in me independently of my will. For Geulincx, the given or found character of these thoughts is incompatible with the possibility of my mind being the author of them. "Givenness"22 and efficacy exclude each other, for efficacy brings into existence something that was not there before, i.e., that was not given. Now, Geulincx argues, if I am not the cause of these thoughts, something other than me must cause them, for it is impossible that they come from nothing or merely happen spon-

19 OP 2:148: "Varios habeo cogitandi modos in infinitum."

20 OP 2:149: "Ego sum res una atque simplex."

21 OP 2:149.

22 I employ the notion of the "given" here in a similar way to how Salomon Maimon would characterise it a century later in his Versuch über die Transzendentalphilosophie (Berlin: C.F. Voss, 1790), 203: "Eine Vorstellung, deren Enstehungsart in uns, uns unbekannt ist" ("a representation whose means of origination in us is unknown to us”). 
taneously. It might seem at first that they come from my body, but I still do not know whether a body can produce such sensations in me and, if so, how.

We thus arrive at the central insight of Geulincx's self-explorative approach, the one that will enable him to go beyond the limited scope of the ego. We have just seen that the infinite variety of thoughts in me that I have not produced must come from something other than me. Now, the otherness that causes all these thoughts in me must be aware that it causes them and of how it causes them; knowledge must necessarily accompany the production of all these modi cogitandi. Geulincx observes that this requirement-i.e., no causation without knowledge-is actually a self-evident principle, which we only fail to grasp due to deeply entrenched prejudices. For instance, we are used to thinking that when we approach a fire and feel warmth, the fire produces that warmth. In like manner, we assume that the sun produces light and that a waterfall produces a particular noise. Put differently: we unjustifiably assume that things that are devoid of thought can be efficacious and bring about certain effects. Yet this prejudice dissolves as soon as we pay heed to the following selfevident truth: "That which you do not know how to do, you do not do" ("quod nescis quomodo fiat, id non facis"; henceforth, the quods nescis principle). ${ }^{23}$ To make this principle clearer, recall that consciousness is the only measuring stick or valid criterion in Geulincx's inquiry and that we are not allowed to illegitimately introduce extra-mental elements. Since we do not know of any efficacy except the one we immediately experience in ourselves-i.e., one accompanied by knowledge-the notion of efficacy only has meaning within the mental sphere. ${ }^{24}$ From this, it follows that the

23 OP 2:150. Concerning the historical roots of the principle quod nescis, which go back to Galen's De Foetus Formatione, see Emanuela Scribano, “'Quod nescis quomodo fiat, id non facis.' Occasionalism against Descartes?," Rinascimento 51 (2011), 63-86; see also Andrea Sangiacomo, "Geulincx and the Quod Nescis Principle," in The Oxford Handbook of Descartes and Cartesianism, ed. Steven Nadler, Tad M. Schmaltz, and Delphine Antoine-Mahut (Oxford: Oxford University Press, 2019), 450-64. In his illuminating study, Sangiacomo shows that the quod nescis principle is alien to Cartesian philosophy and rather has its roots in late Scholastic thought. According to Sangiacomo, this principle can equally be used to support the autonomy and efficacy of natural agents vis-à-vis God (namely, by attributing knowledge to them) and to restrict causal efficacy to God alone (by depriving natural beings of knowledge). Geulincx is clearly interested in the second use, and he thus attempts to integrate the principle into Descartes's dualistic framework, which reduces the natural world to mere extension (deprived of thought). This operation enables him to philosophically underpin the Calvinistic view according to which God alone governs all events. Thus, Sangiacomo argues, Geulincx's endorsement of the quod nescis principle serves a specific agenda dictated by his Calvinistic creed. Concerning Geulincx's attempt to elaborate an ethical system (based on Cartesian premises) consistent with Calvinism, see van Ruler, "Geulincx and Spinoza: Books, Backgrounds and Biographies."

24 Regarding Geulincx's "subjective" or "mental" approach to the idea of causation-which distinguishes him from the rest of the occasionalists-see Ursula Renz \& Han van Ruler, "Okkasionalimus," in Enzyklopädie Philosophie, ed. Hans Jörg Sandkühler (Hamburg: Felix Meiner, 2010), 2:1843-46. Hume's rejection of volitional efficacy features striking parallels with Geulincx's use of the quod nescis principle. Regarding the possible connection between the two thinkers, see Jason Jordan, "Voli- 
otherness that produces all these modi cogitandi in me cannot be something that is brutish and devoid of thought. The fire cannot produce the feeling of warmth in me, just as the sun is per se unable to illuminate. The cause of all these effects must be a being endowed with consciousness and will, which knows exactly how to produce them. We must thus conclude (fifth discernment): "There is someone who knows and wills who is different from me" ("est sciens aliquis et volens diversus a me"). ${ }^{25}$ Aside from my own existence as a thinking being, I must admit the existence of another thinking being that induces those perceptions in me for which I am not responsible.

This fifth discernment is full of consequences and contains Geulincx's entire philosophy in embryonic form. Let us briefly consider some of its far-reaching implications. We have seen that the "givenness" of certain thoughts excludes the possibility of me being their cause. If I were their cause, I would know how to produce them, and therefore I would not merely find them in myself, independent of my will. Thus, the given character of certain thoughts in me indicates the limitation of my intellect, which would be perfect if it were the cause of all its thoughts. A perfect mind does not find anything-i.e., it is not passive or receptive-and therefore it is the only author of its thoughts and perceptions. I am therefore limited and imperfect, insofar as I am passive and receptive. Yet I am not passive with regard to something that is not, in turn, a mind. Something devoid of thought-such as a body-cannot act upon me, for, as repeatedly observed, there is no causation without knowledge. Behind the impressions I have not produced, there is not an unknown thing, but the unknown action of another mind. Therefore, if I am limited and passive, it is so necessarily with regard to an unlimited mind. Another way of saying this is that I am a limited intellect within an unlimited, all-embracing intellect, and my being part of it accounts for both my thinking power and my cognitive imperfection. ${ }^{26}$ Guelincx can thus affirm: "We are from God and belong to God; we are not God Himself, because of our limitations and imperfections, with respect to which we do not belong to God,

\footnotetext{
tional Efficacy and the Paralytic's Arm: Hume and the Discursus of Occasionalism," Intellectual History Review 25, no. 4 (2015): 401-12.

25 OP 2:150.

26 We find a somewhat similar explanation of our cognitive imperfection in Spinoza. See his Treatise on the Emendation of the Intellect, in Opera, edited by Carl Gebhardt (Heidelberg: Carl Winter, 1925), 2:28; The Collected Works of Spinoza, edited and translated by Edwin Curley (Princeton: Princeton University Press, 1985-2016), 1:33: "But if it is-as it seems at first-of the nature of a thinking being to form true, or adequate, thoughts, it is certain that inadequate ideas arise in us only from the fact that we are part of a thinking being, of which some thoughts wholly constitute our mind, while others do so only in part" ("Quod si de natura entis cogitantis sit, uti prima fronte videtur, cogitationes veras sive adaequatas formare, certum est, ideas inadaequatas ex eo tantum in nobis oriri, quod pars sumus alicuius entis cogitantis, cuius quaedam cogitationes ex toto, quaedam ex parte tantum nostrum mentem constituunt”).
} 
for they do not belong to our being, but to non-being." ${ }^{27}$ Observe that just as our limitations and imperfections do not belong to God, nor do they belong to us, for limitation is simply a lack of being, and hence our being is not different from God's. Geulincx illustrates this point immediately afterwards with the following simile (which drew him accusations of Spinozism): just as a vast prairie is divided into parcels, our minds can be considered parcels or sub-regions of God's unlimited mind. ${ }^{28}$ If you remove the parcels-i.e., the limitations-there remains only a continuous and unlimited space. Similarly, if you remove our cognitive limitations, there is only an infinite mind. ${ }^{29}$ We can thus see how Geulincx's self-explorative approach, together with the quod nescis principle, enables him to reestablish the continuity between the infinite and the finite and to embrace a form of mental holism. It is noteworthy that Geulincx arrives at this bold conclusion without ever abandoning the element of thought; i.e., by focusing on our consciousness alone and without presupposing anything previously known. ${ }^{30}$ I observed in the previous section that for Geulincx, scepticism is the negative flipside of the knower's priority over the known. Now we can affirm that mental holism is the positive flipside of Geulincx's scepticism.

Yet although Geulincx advocates mental holism-i.e., that all minds are but one mind-he does not thereby advocate idealism; i.e., that the whole of reality is of a mental nature. As I will show in the next section, he contends that God causes an infinite variety of thoughts in me through the mediation of the body. Hence, there is after all something external to the mind, which is not just another mind, but something cor-

27 OP 2:269: "Nos sumus ex Deo et pertinemus ad Deum; non sumus tamen ipse Deus, propter limitationes et imperfectiones nostras, respectu quarum ad Deum non pertinemus, quia non pertinent ad nostrum esse, sed ad non-esse."

28 OP 2:269; also 293. Rousset argues (Geulincx entre Descartes et Spinoza, 86) that our mind's containment within God's mind is not to be taken literally, but rather in the sense that our minds are imperfect instantiations of God's perfect mind. Rousset's main reason for rejecting mental holism in Geulincx is the fact that Geulincx still conceives the relationship between God and His creatures in terms of "creation," a notion that in Rousset's opinion is clearly incompatible with holism or monism. Against Rousset, it must be noted that Geulincx explicitly equates “creation” with God's "selflimitation." See the following passage from his Annotata latiora in Principia Philosophiae Renati Descartes (OP 3:381): "Quod Deus creare possit, ab aeternitate sua habet; cum enim inde primus sit, atque ideo etiam illimitatus, potest etiam ille aliis quibusdam, quod in se eminentissime et illimitate habet, limitate communicare, dando illis portionem istius naturae, quam ille sibi totam et illimitatam vindicaverat. Limites enim ponendo certis suis perfectionibus, eas quodammodo alienat et extrase ponit, easdem tamen sibi retinens quatenus illimitatae sunt.” Regarding Geulincx's account of creation as self-limitation, see Brian Cooney, “Arnold Geulincx: A Cartesian Idealist," Journal of the History of Philosophy 16, no. 2 (1978): 167-80.

29 OP 2:239: "Remove enim a te limitationem illam, qua intellectus tuus ita circumscriptus est, ut in futurum prospiciat nihil, de praeteritis pauca recolat, de praesentibus non multa sciat, multa de rerum natura ambigat, multa ignoret; his omnibus limitationibus [...] ablates, quid nisi Deum ipsum, infinitam mentem a qua praecisus fueras, apprehendis?"

30 He himself stresses this (OP 2:239; italics mine): "Et certe cum bene hanc rem perpendimus, nos ipsos examinando, cum id quod ad praecisionem, abstractionem, limitationemque pertinet, a nobis removerimus, clarissime Deum ipsum in nobis agnoscimus et nos in illo." 
poreal and devoid of consciousness. Yet this does not change any of the implications just drawn concerning the fifth discernment. Since causation requires knowledge, I cannot properly say that fire causes warmth in me, but rather that God uses fire as an instrument to produce warmth in me. Here, we can recognise Geulincx's occasionalism; i.e., the view that only God has causal efficacy. By establishing that there is no efficacy without consciousness, Geulincx is committed to affirming the existence of an omniscient being that concentrates all efficacy in itself. Certainly, the mere principle of quod nescis does not deprive me of all efficacy: although I am passive regarding certain thoughts, I am the actual source of others, such as my intentions, volitions, consents, denials, and the like. Yet, in any case, I cannot bring about anything beyond my own mental sphere without the assistance of another (knowing) being. For instance, I cannot move my own legs solely in virtue of myself, for I cannot exert an action on a thing that I have not produced, such as my body, even if I feel it to be "mine." My body is something given to me, and therefore something that is foreign to my knowledge and as such a sign of my mental limitations. In every action of mine in which something foreign to my mind is involved, I cannot be the only cause, and the concurrence of another knowing being therefore is indispensable. Consider now the entire created world as an infinite aggregate of finite beings-be they minds or bodies-interacting with one another. Their interaction is inconceivable without God effecting it, for bodies are devoid of efficacy and particular minds do not cause anything beyond the sphere of their consciousness. Hence, we must conclude that an unlimited omniscient being connects all particular things with one another and constitutes their unifying principle. The words of the apostle thus receive their proper philosophical meaning (Acts 17:28): "For in him we live, and move, and have our being" ("in ipso enim vivimus, et movemur, et sumus"). ${ }^{31}$

\section{Multiplicity, Time, and Corporeality}

After demonstrating that an infinite mind causes those thoughts in me for which I am not responsible, Geulincx goes on to demonstrate that it produces these thoughts by means of a body, not immediately. To show this is the purpose of the sixth and seventh discernments of the Autology, in which Geulincx's reasoning becomes somewhat obscure. His argument, in broad strokes, runs as follows. Recall that the human mind is something simple and undivided: I am one and the same throughout my various mental states. God is also a mind, and hence is equally simple and undivided. Now, since variety cannot emanate from something simple (at least directly), the variety of thoughts I find in myself cannot emanate either from me or from God. Such variety is only explainable by means of something intrinsically multiple or susceptible to multiplicity. Such is the case with matter (or extension),

31 OP 2:239; also 293. 
which-in contrast to the mental-admits division and multiplicity. Yet the mere notion of extension does not entail division, but merely susceptibility to being divided. Considered in itself, extension is something homogeneous and uniform. In order for multiplicity to emerge from mere extension, there must also be motion, which, together with matter, generates the diversity of figures we encounter in the corporeal world. ${ }^{32}$ Since mere corporeality is unable to generate motion, God must be the one who-by a contingent decree of His will-introduces motion, and hence variety, into the corporeal world. ${ }^{33}$ The diversity of my thoughts is thus due to the diversity introduced by God in inert extension. It might seem here that Geulincx betrays his own self-explorative approach by surreptitiously introducing an unjustified assumption; namely, the existence of a corporeal world besides the mental. If, up to this point, Geulincx has remained within the limits of a mere self-inspection, the sudden talk of corporeality in the sixth and seventh discernments seems to violate this restriction. At first glance, it is also unclear why Geulincx needs to introduce corporeality (and motion) in order to account for the diversity of our thoughts. We have seen that the "givenness" of our thoughts indicates the existence of another mind, which -in contrast to ours-is unlimited and able to generate impressions in us without our will. If our containment in God's mind already accounts for our limitation and passivity, and hence for the existence of "given" thoughts in us, why does Geulincx additionally need to invoke something extra-mental? Why can he not attribute the variety of our thoughts directly to God's efficacy? Clarifying this question is the goal of the following considerations.

Despite appearances, the introduction of the corporeal in this context is far from gratuitous (although its actual justification appears much later in the text, in the Somatology). ${ }^{34}$ The key to the present difficulty lies in the notion of time. Time and succession presuppose motion, for if everything were at rest, it would make no sense to talk about time. Motion, in turn, presupposes corporeality, for only bodies are susceptible to motion. Now, I am conscious of time and there is a certain succession of mental states in me. Hence, since time presupposes motion, there must be bodies in motion, and therefore a physical world! Note that Geulincx is not saying that physical motion (from which time derives) causes a variety of mental states in me, but rather that God uses physical motion as a means to produce this variety of mental states. As already noted, entities devoid of thought such as bodies are unable to produce anything by themselves, either among themselves or in me as a thinking being. God is therefore ultimately responsible for the succession of mental states in me. Yet since time is inconceivable without physical motion, the temporality of my mental states necessarily requires the mediation of the corporeal. The gist of Geulincx's argu-

32 For Geulincx, division and motion are the same thing. See OP 2:279, ad pag. 176.

33 The idea that physical motion can only be caused by a mind would reappear, outside of occasionalist circles, in George Berkeley's essay De motu, written and published in 1721. See The Works of George Berkeley, ed. Alexander Campbell (Oxford: Clarendon Press, 1901), 1:487-527.

34 OP 2:176-77. 
ment is the following: if the mind were the only existing reality, there would be neither plurality nor mutability, only a rigid and undifferentiated simplicity. ${ }^{35}$ Difference and mutability are foreign to pure thought, which-as the third discernment has already shown-is one and simple. Therefore, besides pure thought, we must assume the existence of a being capable of being modified, differentiated and divided, in order to account not only for the temporality of mental states, but also for the existence of difference and multiplicity as such. We only find such susceptibility in the corporeal. Certainly, God's creation of a corporeal world and the suffusion of motion in it are incomprehensible events for us. The emergence of multiplicity and mutability from the divine mind, although an undeniable fact, is a mystery beyond our cognitive grasp. ${ }^{36}$ I will return to this point in the next section.

The demonstration that God acts on us by means of the corporeal allows Geulincx to explain other things, such as the union of my mind with a particular body -i.e., "my" body-as well as the dissolubility of such a union (which opens the door to a proof of the mind's immortality). Moreover, the introduction of the corporeal into the philosophical inquiry sets the basis for a physical doctrine of a Cartesian nature, which Geulincx presents in his Somatology and develops in his True Physics (Physica vera). ${ }^{37}$ However, dealing with these issues would go beyond the boundaries of this paper. In any case, Geulincx's demonstration of the existence of a corporeal world by means of the notion of time appears to be if not forceful, then at least plausible. As a good Cartesian, Geulincx takes extension and thought as the most fundamental notions and the supreme genera of things. ${ }^{38}$ Just as the mental is a primary reality, unexplainable by something other than the mind itself, the physical has essential features that cannot be deduced from the mental alone. ${ }^{39}$ In this respect,

35 Here, Geulincx touches upon a difficulty that would become crucially important in German Idealism; namely, the origin of difference and non-identity. Whereas thinkers like Fichte would take nonidentity as external to thought, Hegel would attempt to conceive non-identity as intrinsic to thought (i.e., identity) itself.

36 We should not forget, however, that Geulincx attempts to provide a rational account of the idea of "creation." See note 28 above.

37 OP 2:368-457.

38 See Descartes’s Principles of Philosophy, § 48, in Euvres de Descartes, ed. Charles Adam and Paul Tannery (Paris: Vrin, 1974-1989) 8:23; Philosophical Writings of Descartes, ed. and trans. John Cottingham, Robert Stoothoff, Dugald Murdoch (vols. 1 and 2), and Anthony Kenny (vol. 3) (Cambridge and New York: Cambridge University Press, 1984-1991), 1:208: “But I recognize only two ultimate classes of things: first, intellectual or thinking things, i.e. those which pertain to the mind or thinking substance; and secondly, material things, i.e. those which pertain to extended substance or body" ("Non autem plura quam duo summa genera rerum agnosco: unum est rerum intellectualium, sive cogitativarum, hoc est, ad mentem sive ad substantiam cogitantem pertinentium; aliud rerum materialium, sive quae pertinent ad substantiam extensam, hoc est, ad corpus"). On this point (as in many others), Spinoza also appears to be very close to his contemporary and compatriot Geulincx, as they both endorse a holism with respect to both the mental and the corporeal.

39 It should be clarified that the irreducibility of the corporeal to the mental only holds for us (quoad nos), finite minds, insofar as the infinite's mind creation of extension is beyond our comprehension. 
for Geulincx, thought and extension are-as de Vleeschauwer fittingly puts it"transcategorial realities" independent of our knowledge. ${ }^{40}$ Note that that which initially looked like an unattainable goal-i.e., knowledge of things as they are in themselves-now appears to be the necessary outcome of a self-inspection that is distrustful of our cognitive powers. The initial scepticism has thus developed into a limited, yet indisputable knowledge. From the objective vantage point thus attained, it is now possible to look at the common misconceptions of philosophers and unmask the mechanism behind them. As Spinoza repeatedly stresses, "veritas index sui et falsi": the true accounts for itself and for its opposite, the false. In accordance with this principle, Geulincx attaches to his True Metaphysics an annex entitled Metaphysics according to the Peripatetic Mind, ${ }^{41}$ where he critically examines the basic notions of Scholasticism, which for him is the philosophical expression of common sense. In order thus to complete our brief exposition of Geulincx's epistemological views, it is pertinent to take a brief look at this work.

\section{Anti-Dogmatism and the Critique of Scholasticism}

In his Metaphysics according to the Peripatetic Mind, Geulincx declares Peripatetic philosophy false from the very outset. ${ }^{42}$ In accordance with the classification presented in the second section, this kind of philosophy is a consideration of things relative to us, hence devoid of objective validity. For Geulincx, the falsity of Peripatetic philosophy comes from its naive pretension of directly exploring things without previously exploring the knower itself. Peripatetic philosophy barely problematises our cognitive access to reality, and thus it takes mere appearances-both sensitive and intellectual-for the things themselves. Insofar as it assigns to the things themselves that which is only relative to us, this kind of philosophy is dogmatic. Geulincx's main purpose in this text is thus to surmount dogmatism from within by showing the de-

Quoad se, however, the corporeal entirely derives from the mental, for the corporeal is passive, and the passive is necessarily posterior (not in temporal terms, but ontologically and conceptually) to the active. See OP 2:160-61.

40 H.J. de Vleeschauwer, "Les antécédants du transcendentalisme." Thus, Geulincx claims (OP 2:240): "Videmus itaque duas res singulares, mentem inquam atque corpus, creditas hactenus ut universales: illam Deum [...], hoc vero creaturam." As already indicated in the previous note, we should avoid construing the distinction between thought and extension as a rigid dualism, for Geulincx equally maintains that extension is "eminently" contained in God (see OP 2:300). In this regard, Cooney convincingly argues (see "Arnold Geulincx: A Cartesian Idealist") that extension is only "external" to finite minds, not to God, who comprehends everything.

41 OP 2:199-265.

42 Concerning Geulincx's criticism of Aristotelianism in conjunction with that of Bacon and Descartes, see Aalderink, Philosophy, Scientific Knowledge, and Concept Formation in Geulincx and Descartes, $17-64$. 
ficiencies of its conceptual apparatus. I want to focus on Geulincx's critical examination of two conceptual pairs that are characteristic of Scholasticism: universality and singularity on the one hand and essence and accident on the other. The upshot of Geulincx's critical assessment will roughly be the following: that which is the most impenetrable and obscure for Scholastic philosophy is actually the most knowable for the human mind. Conversely, that which Scholasticism takes as the most knowable is actually the most obscure. Thus, for Geulincx, God's intellect before creating the world is the most accessible for the human mind, whereas the created world is the most impenetrable.

In the section dedicated to universality and singularity, ${ }^{43}$ Geulincx focuses his attention on the main intellectual operation of Scholastic philosophy: abstraction. ${ }^{44}$ It is through abstraction that Peripatetic thought generates its basic concepts, such as being, substance, the one, etc. Abstraction consists in separating by means of the intellect a particular content from the integral whole to which it belongs and considering it in an isolated manner. When the separated content is a feature common to various individuals, the product of abstraction is a universal concept. In the case of the most general concepts, such as being or substance, the common feature is not a particular content (for such concepts are devoid of content), but an objectified mental operation. ${ }^{45}$ There are cases in which abstraction does not separate something common to many, but instead simply one thing from another, such as when we abstract a point from a line or a line from a surface. In any case, abstraction is nothing but a mental operation that does not change anything in the nature of things. Yet Geulincx also observes-quoting Aristotle-that "those who abstract do not lie" ("abstrahentium non est mendacium"). ${ }^{46}$ That is, we must concede that universals exist in the things themselves, for abstraction selects "something" existing in reality (otherwise it would not be something). However, we should not thereby assume that the thing thus abstracted exists in exactly this way; i.e., differentiated from the rest. Thus, the actual risk of abstraction consists in attributing a separate and independent existence to something that can only exist as part of something else.

To illustrate this point, take, for instance, the notion of body. Particular bodies are finite and have a specific shape. If we select these features and universalise them, we might erroneously conclude that the body or the corporeal as such (simpliciter) is essentially finite and has a shape. Yet corporeality in itself is not the result of artificially separating (or abstracting) certain features common to particular bodies; rather, par-

43 OP 2:235-40.

44 Regarding Geulincx's theory of abstraction in the context of seventeenth-century debates on abstraction, see again Aalderink, Philosophy, Scientific Knowledge, and Concept Formation in Geulincx and Descartes, 323-49.

45 Gabriel Nuchelmans traces Geulincx's reflections on this issue back to the scholastic distinction between actus exercitus and actus significatus. See Gabriel Nuchelmanns, Judgment and Proposition from Descartes to Kant (Amsterdam: North-Holland Publishing Company, 1983), 100-104.

46 OP 2:236. 
ticular bodies are abstractions of the only existing body-i.e., extension-which as such is unlimited and without shape. As we can see, the validity of abstraction depends on how we apply the distinction between the absolute and the relative. Since abstraction artificially separates things that originally belong together, the abstracted content is necessarily relative to the integral whole from which it has been separated. Abstraction can thus never provide access to an absolute and self-contained reality. Put differently: we do not know what corporeality as such is by isolating features from particular bodies, but by removing all particularities and delimitations that we have superimposed onto the corporeal. The corporeal nature manifests itself when we eliminate its finite appearances. The same applies to the mind: particular minds are limited and imperfect, but if we remove all particularity, we will grasp the mind as such, which is unlimited and perfect (recall the analogy with the prairie and its parcels in the second section). In this respect, Geulincx observes that properly speaking, we should not talk about bodies and minds, but about corporeal things and mental things. ${ }^{47}$ In sum: abstraction separates the finite from the infinite, whereas in fact the finite-i.e., the delimited, the abstract-exists only within the infinite and must be conceived through it. Note that the removal of all particularity that Geulincx commends as the right way of grasping reality-as opposed to abstraction-coincides with the sceptical scruple discussed in the second section. Only the distrust towards our own subjective forms and modi dicendi ("ways of speaking") enables us to examine thought as such-i.e., in an absolute manner-thus transcending all relativity.

Let us now pass to the notions of essence and accident. ${ }^{48}$ Essential is a predicate that necessarily belongs to a thing, so that it is impossible to deny it of it. Thus, the essence of the body is to be extended, and the essence of the mind is thought. There are also certain "secondary" properties that we can deduce through reasoning from a thing's essence, such as infinity from extension, its infinite divisibility, etc. There are, furthermore, predicates of a thing that do not necessarily belong to it, so that we can conceive the thing without them. Motion, for instance, presupposes extension, but does not immediately derive from it, as the fact that we can conceive of extension without motion makes clear. The connection between these two notions is contingent-we could also say "accidental"-for we cannot move from the one to the other through an interrupted reasoning. For Geulincx, there cannot be any science of the contingent due to this gap in the reasoning or scala rationis. The existence of contingent things depends solely on God's will, which Geulincx-following Descartes-clearly distinguishes from God's intellect. To the class of contingent things belong the world, the sun, the earth and its parts, human beings, etc. All these things fall outside of the realm of the rational, for no demonstration can explain why they exist. Yet the impossibility of "deducing" the contingent is not incompatible with tracing the root of contingent things. As already shown, Geulincx can demonstrate

47 OP 2:286-87.

48 OP 2:261-65. 
the existence of a corporeal world by virtue of the notion of time, which presupposes motion, which in turn presupposes extension. Although the upwards reasoning from time to extension is valid, the downwards reasoning from extension to time is not. From the existence of contingent things, we can infer the existence of a creator, but the existence of contingent things as such is rationally unaccountable, for it exclusively depends on God's decree.

If we now connect these considerations with Geulincx's reflections on abstraction, we can see that in a way, the contingent and the finite (or abstract) coincide. As already observed in the previous section, motion generates the variety and multiplicity of things in the corporeal world. Moreover, particular things-be they minds or bodies-are abstractions from unlimited realities without which they cannot be properly conceived, yet from which they cannot be deduced. The whole realm of the finite and contingent is thus rationally unaccountable for us. This realm constitutes the point of departure of Peripatetic philosophy, from which it attempts to ascend to the apprehension of the absolute and unconditioned. Yet we have seen that the particular cannot provide access to the absolute. For this reason, Geulincx affirms that Scholastic philosophy has an obscure notion of infinite realities. By contrast, for Geulincx, infinite realities-such as thought and extension-are the only ones that are transparent to the human mind, as long as it refrains from grasping the particular and focuses on the inspection of its own self. Whereas Scholastic philosophy remains imprisoned in a world fashioned by our subjective view of things, the intellectual itinerary proposed by Geulincx elevates the mind to the "transcategorial," yet at the cost of alienating it from the existing world.

\section{Conclusion}

Geulincx's rich thought comprises further aspects that require a separate examination, such as a full-blown ethical system, ${ }^{49}$ a relatively innovative logic, ${ }^{50}$ and an out-

\footnotetext{
49 See Ethics (Ethica) in OP 3:1-271. The first part of Geulincx's Ethics appeared in 1665 under the title De Virtute et Primis Ejus Proprietatibus. Ten years later (six years after Geulincx's death), the complete Ethics was published. There is an English translation (which includes Samuel Beckett's notes): Ethics, with Samuel Beckett's Notes, trans. Martin Wilson, ed. Han van Ruler, Anthony Uhlmann, and Martin Wilson (Leiden and Boston: Brill, 2006). Geulincx's ethics features striking parallels with Stoicism that have been explored by Ruben Buys, "Between Actor and Spectator: Arnout Geulincx and the Stoics," British Journal for the History of Philosophy 18, no. 5 (2010): 741-61. Regarding Spinoza’s and Geulincx's respective approaches to human passions, see Mark Aalderink, "Spinoza and Geulincx on the Human Condition, Passions, and Love,” Studia Spinozana 15 (2006): 67-87.

50 His main works in this area are Logica fundamentis suis restituta (OP 1:165-454) and Methodus inveniendi argumenta (OP 2:1-111), the first of which appeared the same year as La logique ou l'art de pensar by Arnauld and Nicole (1662). For instructive accounts of Geulincx's logic, see Nuchelmans, Judgment and Proposition from Descartes to Kant, 99-120; also Karl Dürr, "Arnold Geulincx und die klassische Logik des 17. Jahrhunderts,” Studium Generale 18 (1965-68): 520-41.
} 
dated yet quite elaborate physics. ${ }^{51}$ In this paper, I have confined myself to what I take to be the core of his philosophy; namely, the self-explorative approach developed in his Autology. This approach is a fine example of how scepticism, far from hindering philosophical inquiry, can in fact significantly expand its scope. Hegel famously stated that scepticism is "the free side of every philosophy," insofar as it raises the mind above the limitation and one-sidedness of common sense. ${ }^{52}$ In Geulincx's case, scepticism presumably liberates the mind from its subjective forms and its modi dicendi, thus revealing that the mind is one and infinite and that our finite mind is just a parcel of it. Furthermore, the temporality of our mental states indicates the existence of bodily motion-without which there would be no temporality-and hence the existence of a physical realm beyond the mind itself. Geulincx's self-inspection thus results in the attainment of two "transcategorial" realities, the mental and the physical. One could justifiably ask here whether these realities are indeed as "transcategorial"-i.e., independent of our knowledge-as Geulincx pretends. Just as Geulincx sharply criticises the conceptual apparatus of Scholasticism for being merely "subjective," he could equally have questioned the objectivity of the (Cartesian) distinction between the mental and the corporeal and subjected it to a critical examination. Yet here we encounter-as Cassirer rightly put it-“the inner limit" of Geulincx's anti-dogmatism. ${ }^{53}$ Despite his efforts to disembarrass himself from uncritical assumptions, Geulincx still thinks in Cartesian terms, even if he departs from Descartes in crucial respects. Thus, he cannot be critical of Cartesian philosophy to the same extent that he is of Scholasticism, precisely because Descartes provides him with the conceptual resources to rebut Scholasticism. This does not mean, however, that Geulincx accepts the Cartesian understanding of the mental and the physical without further ado. As has been shown, he attempts to purify these notions of all traces of "reifying" thinking, a purification that results, among other things, in the de-substantialisation of the human mind and its localisation within the divine intellect. Spinoza arrived at the same conclusion, based on the same Cartesian premises. A separate study is required to show the differences and similarities of their respective approaches.

51 See his Physica Vera (OP 2:368-446) and his Physica Falsa s. ad mentem Peripateticorum (OP 2:313-67). For a good summary of Geulincx's physics, see Rousset, Geulincx entre Descartes et Spino$z a, 101-28$.

52 Georg Wilhelm Friedrich Hegel, Verhältnis des Skeptizismus zur Philosophie, in Jenaer Schriften 1801-1807, ed. Eva Moldenhauer and Karl Markus Michel (Frankfurt am Main: Suhrkamp Verlag, 1986), 229.

53 Cassirer, Erkenntnisproblem, 1:540-41. 


\section{Bibliography}

Aalderink, Mark. Philosophy, Scientific Knowledge, and Concept Formation in Geulincx and Descartes. Utrecht: Zeno, 2010.

Aalderink, Mark. "Spinoza and Geulincx on the Human Condition, Passions, and Love." Studia Spinozana 15 (2006): 67-88.

Ayers, Michael R. "Richard Burthogge and the Origins of Modern Conceptualism." In Analytic Philosophy and History of Philosophy, edited by Tom Sorell and G.A.J. Roger, 179-200. Oxford: Clarendon, 2005.

Bardout, Jean-Christophe. "Occasionalism: La Forge, Cordemoy, Geulincx." In A Companion to Early Modern Philosophy, edited by Steven Nadler, 104-51. Malden, MA: Blackwell, 2002.

Berkeley, George. The Works of George Berkeley. Edited by Alexander Campbell Fraser. 4 vols. Oxford: Clarendon Press, 1901.

Burthogge, Richard. An Essay upon Reason and the Nature of Spirits. London: Dunton, 1694.

Buys, Ruben. "Between Actor and Spectator: Arnout Geulincx and the Stoics." British Journal for the History of Philosophy 18, no. 5 (2010): 741-61.

Cassirer, Ernst. Das Erkenntnisproblem in der Philosophie und Wissenschaft der neueren Zeit, 3rd ed. 3 vols. Berlin: Bruno Cassirer, 1922.

Clatterbaugh, Kenneth. The Causation Debate in Modern Philosophy 1637-1739. New York: Routledge, 1999.

Cooney, Brian. "Arnold Geulincx: A Cartesian Idealist.” Journal of the History of Philosophy 16, no. 2 (1978): 167-80.

Descartes, René. Euvres de Descartes. Edited by Charles Adam and Paul Tannery. 11 vols. Paris: Vrin, 1974-1989.

Descartes, René. The Philosophical Writings of Descartes. Translated by John Cottingham, Robert Stoothoff, Dugald Murdoch (vols. 1 and 2); Anthony Kenny (vol. 3). 3 vols. Cambridge: Cambridge University Press, 1984.

Dürr, Karl. "Arnold Geulincx und die klassische Logik des 17. Jahrhunderts. “ Studium Generale 18 (1965-68): 520-41.

Geulincx, Arnold. Arnoldi Geulincx Antverpiensis Opera Philosophica. Edited by Jan Pieter Nicolaas Land. 3 vols. Den Haag: M. Nijhoff, 1891-93.

Geulincx, Arnold. Ethics, with Samuel Beckett's Notes. Translated by Martin Wilson. Edited by Han van Ruler, Anthony Uhlmann, and Martin Wilson. Leiden and Boston: Brill, 2006.

Hegel, Georg Wilhelm Friedrich. Jenaer Schriften 1801-1807. Edited by Eva Moldenhauer and Karl Markus Michel. Frankfurt am Main: Suhrkamp Verlag, 1986.

Jordan, Jason. "Volitional Efficacy and the Paralytic's Arm: Hume and the Discursus of Occasionalism." Intellectual History Review 25, no. 4 (2015): 401-12.

de Lattre, Alain. L'occasionalisme d'Arnold Geulincx: étude sur la constitution de la doctrine. Paris: Éditions de Minuit, 1967.

Maimon, Salomon. Versuch über die Transzendentalphilosophie. Berlin: C.F. Voss, 1790.

Nadler, Steven. "Knowledge, Volitional Agency and Causation in Malebranche and Geulincx." British Journal for the History of Philosophy 7, no. 2 (1999): 263-74.

Nuchelmans, Gabriel. Judgment and Proposition: From Descartes to Kant. Amsterdam: North-Holland Publishing Company, 1983.

Perler, Dominik, and Ulrich Rudolph. Occasionalismus: Theorien der Kausalität im arabisch-islamischen und im europäischen Denken. Göttingen: Vandenhoeck \& Ruprecht, 2000.

Renz, Ursula, and Han van Ruler. "Okkasionalimus.” In Enzyklopädie Philosophie, edited by Hans Jörg Sandkühler, 2:1843-46. Hamburg: Felix Meiner, 2010. 
Rousset, Bernard. Geulincx entre Descartes et Spinoza. Paris: Vrin, 1999.

Ruler, Han van, "Geulincx and Spinoza: Books, Backgrounds and Biographies." Studia Spinozana 15 (2006): 89-106.

Sangiacomo, Andrea. "Defect of Knowledge and Practice of Virtue in Geulincx's Occasionalism." Studia Leibnitiana 46, no. 1 (2014): 46-63.

Sangiacomo, Andrea. "Geulincx and the Quod Nescis Principle." In The Oxford Handbook of Descartes and Cartesianism, edited by Steven Nadler, Tad M. Schmaltz, and Delphine Antoine-Mahut, 450-64. Oxford: Oxford University Press, 2019.

Scribano, Emanuela. '“Quod nescis quomodo fiat, id non facis.' Occasionalism against Descartes?" Rinascimento 51 (2011): 63-86.

Specht, Rainer. Commercium mentis et corporis. Über Kausalvorstellungen im Cartesianismus. Stuttgart-Bad Cannstatt: Friedrich Frommann Verlag (Günther Holzboog), 1966.

Spinoza, Benedictus de. Opera. Edited by Carl Gebhardt. 4 vols. Heidelberg: Carl Winter, 1925.

Spinoza, Benedictus de. The Collected Works of Spinoza. Edited and Translated by Edwin Curley. 2 vols. Princeton: Princeton University Press, 1985-2016.

Stein, Ludwig. "Antike und mittelalterliche Vorläufer des Occasionalismus." Archiv für Geschichte der Philosophie 2, no. 2 (1889): 193-245.

de Vleeschauwer, H.J. "Les antécédants du transcendentalisme. Guelincx et Kant." Kant-Studien 45, 1-4 (1953): 245-73.

de Vleeschauwer, H.J. "Three Centuries of Geulincx Research: A Bibliographical Survey." Mededelings van die Universiteit van Suid-Afrika 1 (1957): 1-72.

Zeller, Eduard. 'Über die erste Ausgabe von Geulincx' Ethik und Leibniz' Verhältnis zu Geulincx' Occasionalismus." Sitzungsberichte der Königlich Preußischen Akademie der Wissenschaften zu Berlin 29, no. 2 (1884): 673-95. 